\title{
INHIBITION BY ASPIRIN AND INDOMETHACIN OF UTERINE HYPERTROPHY INDUCED BY AN IUD
}

\author{
G. GHAUDHURI \\ Charing Cross Hospital Medical School, Department of Pharmacology, \\ Fulham Palace Road, London W6 8RF
}

(Received 2nd August 1974)

\begin{abstract}
Summary. An IUD inserted into one uterine horn caused an increase in its weight when this was compared with that of the contralateral control horn in rats. Such an increase could be partly prevented by treating the animals with indomethacin and aspirin. It is suggested that the IUD-induced increase in weight is at least in part mediated by release of prostaglandins.
\end{abstract}

\section{INTRODUCTION}

The presence of an IUD in one horn of the uterus in rats (Parr \& Segal, 1966; Parr, 1969; Saksena, Lau \& Castracane, 1974), rabbits (Ledger \& Bickley, 1966), hamsters (Saksena et al., 1974), and goats (Janakiraman, Shukla, Gadgil \& Buch, 1966) has been shown to cause an increase in the weight of that horn when compared with that of the control horn. It has been suggested that such an increase in weight and uniform growth is due to chronic inflammation even though administration of hydrocortisone failed to suppress such a response (Parr \& Segal, 1966).

It has been suggested that IUDs may act by releasing prostaglandins (Chaudhuri, 1971) and such a release has been shown to occur in rats (Chaudhuri, 1973; Saksena et al., 1974) and in ewes (Spilman \& Duby, 1972). On the basis of such a release, it has been speculated that a continuous release of prostaglandins would lead to a persistent increase in the activity of the uterine horn, and that this could explain the hypertrophy associated with the presence of the device (Chaudhuri, 1973).

The present experiments were carried out to see whether the hypertrophy of uterine horn caused by the introduction of a silk suture in the rat could be prevented by the administration of non-steroidal anti-inflammatory agents (Vane, 1971), which inhibit the synthesis of prostaglandins.

\section{MATERIALS AND METHODS}

Female Wistar rats weighing between 170 and $210 \mathrm{~g}$ were used.

Rats in dioestrus were anaesthetized with ether and the abdomen was opened by a mid-ventral incision. A silk thread $2.5 \mathrm{~cm}$ long was introduced into the 
lumen of one uterine horn and the ends tied to keep it in position. The contralateral horn was subjected to a sham operation and served as a control.

In addition, some rats were bilaterally ovariectomized at the time of introduction of the silk suture.

The non-ovariectomized animals were assigned to six groups and were injected subcutaneously (per kg body weight), starting from the day of operation, with (1) hydrocortisone, $12.5 \mathrm{mg}$, (2) indomethacin, $2 \mathrm{mg}$, (3) aspirin, $10 \mathrm{mg}$ or (4) aspirin, $100 \mathrm{mg}$, or (5) meclafenamate, $2 \mathrm{mg}$.

The rats in the sixth group received no treatment and served as controls.

The ovariectomized rats were assigned to two groups. Those in one group served as controls and the other rats were injected subcutaneously with $2 \mathrm{mg}$ indomethacin $/ \mathrm{kg}$ body weight.

The animals were killed by a blow on the head on the first day of dioestrus after the IUD had been in place for 15 days.

The uterine horns were dissected out and after being blotted slightly were immediately weighed in a Mettler balance for their wet weight. The tissues were then fixed in $10 \%$ formaldehyde and later were blotted and weighed again and then processed for histological examination.

The uterine weight refers to the whole horn, which was excised by cutting at the uterotubal and uterocervical junctions and by trimming away all the mesometrium. The silk suture was also removed before weighing.

The increase in weight of the uterine horn with a silk suture compared to that of the contralateral control horn was calculated as a percentage value for each rat and from this value the mean percentage increase for the groups was calculated.

\section{RESULTS}

In the non-ovariectomized rats, insertion of a silk suture in one horn caused an increase in its wet weight. Administration of hydrocortisone and aspirin, at the lower dose level, failed to inhibit such an increase in weight. Aspirin, at the higher dose level, indomethacin and meclafenamate partly but significantly prevented such an increase. The results for these rats are summarized in Table 1.

In the ovariectomized animals also, an IUD caused an increase in the uterine wet weight when this was compared with that of the contralateral control horns. Administration of indomethacin partly prevented the increase in weight as in non-ovariectomized animals. The results for these rats are summarized in Table 2.

\section{DISCUSSION}

It has been suggested that hypertrophy of the uterine horn containing a foreign body may be due to inflammation (Parr \& Segal, 1966), to an increased sensitivity to oestrogen, or to binding of oestrogen in the affected horn (Pincus, 1964; Kar, Goswami, Kamboj \& Chowdhury, 1964).

Since, however, hypertrophy of the uterine horn containing an IUD still occurs after administration of hydrocortisone (Parr \& Segal, 1966), a potent 
anti-inflammatory agent, and also when the animals are ovariectomized and adrenalectomized (Parr, 1969), it seems probable that other factors in addition to inflammation or increased sensitivity to oestrogen may be involved.

It is now known that the spontaneous contractions of rat uterine horns are mediated by release of prostaglandins (Vane \& Williams, 1973) and that the presence of an IUD is associated with an increase in the spontaneous motility of the horn in vitro compared to that of the control horn (Marcus, Marcus \&

Table 1. The weights of uterine horns containing an IUD and of the contralateral control horns in non-ovariectomized rats subjected to various treatments

\begin{tabular}{|c|c|c|c|c|}
\hline $\begin{array}{l}\text { Treatment groups } \\
\quad \text { (no. of rats) }\end{array}$ & $\begin{array}{l}\text { Mean body wt (g) } \\
\text { at autopsy }(S . E .)\end{array}$ & $\begin{array}{l}\text { Mean wt (mg) } \\
\text { of control horn } \\
\quad(S . E .)\end{array}$ & $\begin{array}{l}\text { Mean wt (mg) } \\
\text { of IUD horn } \\
\quad(\text { S.E. })\end{array}$ & $\begin{array}{l}\text { Mean \% increase } \\
\text { of IUD horn } \\
(\text { S.E. })\end{array}$ \\
\hline $\begin{array}{l}\text { Control } \\
(10)\end{array}$ & $\begin{array}{c}234 \cdot 00 \\
(2 \cdot 86)\end{array}$ & $\begin{array}{l}155 \cdot 50 \\
(12 \cdot 31)\end{array}$ & $\begin{array}{l}287.90 \\
(22 \cdot 90)\end{array}$ & $\begin{array}{c}87 \cdot 63 \\
(10 \cdot 22)\end{array}$ \\
\hline $\begin{array}{l}\text { Hydrocortisone, } \\
12.5 \mathrm{mg} / \mathrm{kg}(9)\end{array}$ & $\begin{array}{c}206 \cdot 11 \\
(8 \cdot 69)\end{array}$ & $\begin{array}{l}146 \cdot 44 \\
(15 \cdot 10)\end{array}$ & $\begin{array}{l}289 \cdot 88 \\
(29 \cdot 49)\end{array}$ & $\begin{array}{l}98 \cdot 73 \\
(4 \cdot 18)\end{array}$ \\
\hline $\begin{array}{l}\text { Aspirin, } \\
\quad 10 \mathrm{mg} / \mathrm{kg}(10)\end{array}$ & $\begin{array}{c}193 \cdot 50 \\
(5 \cdot 16)\end{array}$ & $\begin{array}{l}157.60 \\
(15 \cdot 40)\end{array}$ & $\begin{array}{l}265 \cdot 30 \\
(30 \cdot 09)\end{array}$ & $\begin{array}{l}67 \cdot 97 \\
(9 \cdot 34)\end{array}$ \\
\hline $\begin{array}{l}\text { Aspirin, } \\
\quad 100 \mathrm{mg} / \mathrm{kg}(8)\end{array}$ & $\begin{array}{c}198.25 \\
(3.01)\end{array}$ & $\begin{array}{l}127.75 \\
(11.92)\end{array}$ & $\begin{array}{l}176.50 \\
(19 \cdot 77)\end{array}$ & $\begin{array}{l}37 \cdot 87^{*} \\
(6 \cdot 24)\end{array}$ \\
\hline $\begin{array}{l}\text { Indomethacin, } \\
2 \mathrm{mg} / \mathrm{kg}(12)\end{array}$ & $\begin{array}{c}230 \cdot 83 \\
(3 \cdot 68)\end{array}$ & $\begin{array}{l}164 \cdot 36 \\
(19 \cdot 80)\end{array}$ & $\begin{array}{l}227 \cdot 27 \\
(22 \cdot 89)\end{array}$ & $\begin{array}{l}42 \cdot 52 * \\
(5 \cdot 57)\end{array}$ \\
\hline $\begin{array}{c}\text { Meclafenamate, } \\
2 \mathrm{mg} / \mathrm{kg}(8)\end{array}$ & $\begin{array}{c}193 \cdot 12 \\
(5.97)\end{array}$ & $\begin{array}{l}130 \cdot 37 \\
(14.94)\end{array}$ & $\begin{array}{l}190 \cdot 25 \\
(18 \cdot 08)\end{array}$ & $\begin{array}{l}50 \cdot 34^{*} \\
(13 \cdot 36)\end{array}$ \\
\hline
\end{tabular}

* The mean percentage increase differs significantly $(P<0.001)$ from that of the control group.

Table 2. The weight of uterine horns containing an IUD and of the contralateral control horns in ovariectomized control rats and those treated with indomethacin

\begin{tabular}{|c|c|c|c|c|}
\hline $\begin{array}{l}\text { Treatment groups } \\
\text { (no. of rats) }\end{array}$ & $\begin{array}{c}\text { Mean body wt }(g) \\
\text { at autopsy }(\text { S.E. })\end{array}$ & $\begin{array}{l}\text { Mean wt (mg) } \\
\text { of control horn } \\
(S . E .)\end{array}$ & $\begin{array}{l}\text { Mean wt (mg) } \\
\text { of IUD horn } \\
(\text { S.E. })\end{array}$ & $\begin{array}{c}\text { Mean } \% \text { increase } \\
\text { of IUD horn } \\
(S . E .)\end{array}$ \\
\hline $\begin{array}{l}\text { Control } \\
(9)\end{array}$ & $\begin{array}{l}253 \\
(5 \cdot 17)\end{array}$ & $\begin{array}{l}57 \cdot 55 \\
(9 \cdot 19)\end{array}$ & $\begin{array}{l}141 \cdot 00 \\
(19 \cdot 85)\end{array}$ & $\begin{array}{l}152 \cdot 47 \\
(16 \cdot 99)\end{array}$ \\
\hline $\begin{array}{r}\text { Indomethacin } \\
2 \mathrm{mg} / \mathrm{kg}(9)\end{array}$ & $\begin{array}{l}231 \\
(7.90)\end{array}$ & $\begin{array}{c}60 \cdot 88 \\
(11 \cdot 93)\end{array}$ & $\begin{array}{l}100 \cdot 22 \\
(11 \cdot 34)\end{array}$ & $\begin{array}{l}80 \cdot 54^{*} \\
(14 \cdot 12)\end{array}$ \\
\hline
\end{tabular}

- The mean percentage increase differs significantly $(P<0.005)$ from that of the control group.

Wilson, 1966). This release of prostaglandin can be prevented in rats and ewes by administration of indomethacin (Chaudhuri, 1973; Spilman \& Duby, 1972).

The continuous release of prostaglandin(s) could lead to a persistent increase in the activity of the uterine horn, and thus explain the uterine hypertrophy associated with the presence of an IUD.

Prostaglandins are released as a part of an inflammatory response (Moncada, Ferreira \& Vane, 1973) and inflammation of the uterine horn is usually associated with the use of an IUD (Parr, 1970). When released during inflammation, prostaglandins intensify the effects of other inflammatory mediators and 
therefore aspirin-like drugs reduce but do not abolish the response to an inflammatory stimulus (Moncada et al., 1973). This could explain the ability of meclafenamate, aspirin and indomethacin to reduce significantly, but not to abolish, the IUD-induced hypertrophy of the uterine horn in the present study. The inability of aspirin at the lower dose level to prevent such an hypertrophy may have been due to the low doses used in this study.

The increase in weight of the uterine horns with an IUD seen in ovariectomized rats confirms the observations by Parr (1969) that hypertrophy of such horns can occur even in the absence of oestrogens. The ability of aspirin and indomethacin partly to prevent such an hypertrophy in ovariectomized animals, strengthens the rôle of prostaglandins in this process. Administration of oestrogens (Wilson, 1963) or the presence of an IUD (Parr, 1969) causes nucleoli to appear in the endometrial and stromal cells of the uteri of ovariectomized animals where they are normally absent. Uterine inflammation may also be associated with an increase in nucleoli (Parr, 1969) and their presence may be an indication of the cellular activity involved in the proliferation of fibroblasts and deposition of ground substance (Parr, 1969).

Again, inflammation (Willis, 1969; Giroud \& Willoughby, 1970), oestrogens (Blatchley, Donovan, Horton \& Poyser, 1972) and IUDs (Chaudhuri, 1973; Spilman \& Duby, 1972; Saksena et al., 1974) have the common property of releasing prostaglandins. It is therefore possible that the hypertrophy of the uterine horn seen in these cases is mediated by such a release.

The present experiments clearly demonstrate that the IUD-induced hypertrophy is mediated at least partly by prostaglandins.

\section{ACKNOWLEDGMENTS}

I thank Professor J. B. E. Baker for his valuable suggestions, Mr J. A. Frazer and Mr K. Al-azzawi for technical assistance and Merck, Sharp and Dohme (Berlin) for the supply of indomethacin.

\section{REFERENGES}

Blatchley, F. R., Donovan, B. T., Horton, E. W. \& Poyser, N. L. (1972) The release of prostaglandins and progestin into the uteroovarian venous blood of guinea-pigs during the oestrous cycle and following oestrogen treatment. F. Physiol., Lond. 223, 69-88.

Ghaudhuri, G. (1971) Intrauterine device; possible role of prostaglandins. Lancet, i, 480.

Ghaudhuri, G. (1973) Release of prostaglandins by the I.U.G.D. Prostaglandins, 3, 773-784.

Giroud, J. P. \& WiLloughry, D. A. (1970) The interrelations of complement and prostaglandin like substance in acute inflammation. F. Path. Bact. 101, 241-249.

Janakiraman, K., Shukla, K. P., Gadgil, B. A. \& Buch, N. C. (1966) Effects of intrauterine spirals and hormones on the uterine histology of the ovariectomized goat. F. Reprod. Fert. 11, 145-148.

Kar, A. B., Goswami, A., Kamboj, V. P. \& Ghowdhury, S. R. (1964) Effect of a foreign body on the response of the uterus of ovariectomized rats to oestrogen. Steroids, 4, 159.

LEDGER, W. J. \& BickLEY, J. E. (1966) Effect of a plastic foreign body on the genital tract of the female rabbit. Obstet. Gynec., N.Y. 27, 658-664.

Marcus, S. L., Marcus, G. G. \& Wirson, K. H. (1966) Effect of I.U.C.D. on uterine motility in the rat. Obstet. Gynec., N.Y. 27, 238-242.

Moncada, S., Ferreira, S. H. \& Vane, J. R. (1973) Prostaglandins, aspirin-like drugs and the oedema of inflammation. Nature, Lond. 246, 217-218.

PARR, E. L. (1969) Rôle of inflammation in the uterine weight increase caused by an I.U.D. F. Reprod. Fert. 18, 221-226. 
PArr, E. L. (1970) Leucocytes and infertility. F. Reprod. Fert., Suppl. 10, 153-170.

PARR, E. L. \& SEgAL, S. J. (1966) Effect of an I.U.G.D. on the weight of the rat uterus. Fert. Steril. 17, $648-653$.

Prncus, G. (1964) Discussion on mechanism of contraceptive action. In Intrauterine Contraception, p. 211. Excerpta Medica Foundation, New York.

Saksena, S. K., Lau, I. F. \& Castracane, V. D. (1974) Prostaglandin mediated action of IUDs. 2. F-Prostaglandins (PGF) in the uterine horn of pregnant rats and hamsters with intrauterine devices. Prostaglandins, 5, 97-106.

Spilman, G. H. \& Duby, R. T. (1972) Prostaglandin mediated luteolytic effect of an intrauterine device in sheep. Prostaglandins, 2, 159-168.

VANE, J. R. (1971) Inhibition of prostaglandin synthesis as a mechanism of action of aspirin like drugs. Nature, New Biol. 231, 232-235.

VANE, J. R. \& WILliams, K. I. (1973) The contribution of prostaglandin production to contractions of the isolated uterus of the rat. Br. F. Pharmacol. 48, 629-639.

WILLIs, A. L. (1969) Parallel assay of prostaglandin like activity in rat inflammatory exudate by means of cascade superfusion. F. Pharm. Pharmacol. 21, 126-128.

WiLson, J. D. (1963) The nature of the RNA response to oestradiol administration by the uterus of the rat. Proc. natn. Acad. Sci. U.S.A. 50, 93-100. 